\title{
Antibiotic Administration Along with Endodontic Therapy in the Republic of Croatia: a Pilot Study
}

\section{Primjena antibiotika tijekom endodontskog liječenja u Republici Hrvatskoj: pilot-studija}

\author{
${ }^{1}$ Student of PhD Postgraduate study at School of Dental Medicine University of Zagreb, Croatia \\ Studentica doktorskoga poslijediplomskog studija Stomatološkog fakulteta Sveučilišta u Zagrebu \\ 2 Dental Clinic of the Health Center Križevci, Križevci, Croatia \\ Stomatološka klinika Doma zdravlja Križevci, Hrvatska \\ ${ }^{3}$ Department of Endodontics and Restorative Dentistry, School of Dental Medicine University of Zagreb, Croatia \\ Zavod za endodonciju i restaurativnu stomatologiju Stomatološkog fakulteta Sveučilišta u Zagrebu, Hrvatska \\ ${ }^{4}$ School of Innovation, Design and Engeneering, Mälardalen University, Vàsterås, Sweden \\ Škola inovacija, dizajna i razvoja Sveučilišta Mälardalen, Vlensterås, Švedska \\ ${ }^{5}$ Chair of Farmacology, School of Dental Medicine University of Zagreb, Croatia \\ Katedra za farmakologiju Stomatološkog fakulteta Sveučilišta u Zagrebu, Hrvatska
}

\section{Abstract}

Objective: To evaluate the type and the frequency of antibiotic prescribing along with endodontic therapy in Croatia. The aim is, also, to assess the attitudes of Croatian doctors towards endodontic treatment of patients at risk of developing bacterial endocarditis. Material and methods: Data were collected by a survey questionnaire. Results: $8.4 \%$ of the examined practitioners stated that they prescribe antibiotics often, and $91.6 \%$ of them stated that they prescribed them never/ very rarely/rarely. Most of them (41\%) prescribe antibiotics once or twice a month, $32.5 \%$ once or twice in several months and $20.5 \%$ once or twice a week. The most commonly used antibiotic was penicillin with clavulanic acid. Also, $26.2 \%$ of examined practitioners prescribed antibiotics for gangrene pulp, $51.2 \%$ of them for localized acute apical periodontitis without swelling, $85 \%$ of them for cellulitis, $75 \%$ of them for fever and enlarged lymph nodes, $16.9 \%$ of them for tooth with fistula and $94.1 \%$ of them for prophylaxis of infectious endocarditis. According to the results of study, $54.4 \%$ of dental practitioners did not prescribe antibiotics without intervention on susceptible tooth; $76 \%$ of participants often/almost always/ always accepted endodontic treatment of patients requiring antibiotic prophylaxis to prevent infectious endocarditis, and $96.7 \%$ of participants indicated they were familiar with recent instructions for antibiotic prophylaxis. Conclusion: These findings point to inappropriate use of antibiotics in the practice of 83 dental practitioners questioned regarding the frequency of administration and indications. The most commonly used antibiotic was penicillin with clavulanic acid. A high percentage of surveyed practitioners stated that they were familiar with recent instructions for antibiotic prophylaxis. They also stated that they performed endodontic procedures on patients who were at risk of bacterial endocarditis. There is a noticeable need for targeted continuing education of dental practitioners in the Republic of Croatia.
Received: June 11, 2020

Accepted: August 24, 2020

Address for correspondence Sanja Šegović

University of Zagreb, School of Dental Medicine

Department of Endodontics and

Restorative Dentistry,

Gundulićeva 5, 10000 Zagreb, Croatia Tel:+38514802 111

segovic@sfzg.hr

\section{Introduction}

Endodontic infections, as a part of odontogenic infections, are polymicrobial, involving a combination of grampositive, gram-negative, facultative anaerobes and strict anaerobic bacteria $(1,2)$. For this reason, dentists often prescribe antibiotics as a support to dental treatment or as the only therapy procedure (3). Inappropriate use of antibiotics and the emergence of antibiotic-resistant bacterial strains are global problems in medicine today (4). According to Cope and Chestnutt (5) dentists' prescriptions accounted for approximately $10 \%$ of prescriptions of antimicrobials in primary care. Within the European Union (EU), according to Eu-
Uvod

Odontogene infekcije, uključujući i endodontske, polimikrobne su i kombinacija gram-pozitivnih, gram-negativnih, fakultativnih i striktnih anaerobnih bakterija $(1,2)$ te zbog toga doktori dentalne medicine često propisuju antibiotik kao potporu ili kao jedino sredstvo za liječenje (3). Neracionalna uporaba antibiotika te nastanak bakterijskih vrsta rezistentnih na antibiotike globalni su problemi današnje medicine (4). Prema autorima Copeu i Chestnuttu (5), procjena je da oko $10 \%$ antibiotika propisanih u primarnoj praksi ordiniraju doktori dentalne medicine. U Europskoj uniji (EU), prema podatcima njezina statističkog ureda Eurostata, radi 
rostat data from the EU Statistical Office, there are around 1.8 million doctors of medicine (6) and about 345,000 doctors of dental medicine (7). Therefore, the contribution of individual medical professions to the emergence of antibioticresistant bacterial strains must be considered $(3,5)$.

Sensitivity of oral bacteria to antibiotics has been gradually decreasing and the number of resistant strains is growing, in particular Porphyromonas species and Prevotella species (8). Similar problem has also been reported for alpha hemolytic streptococci (Streptococcus viridans) and for drugs such as macrolides, penicillin and clindamycin $(9,10)$. When bacteria become resistant to antibiotics, they also gain the ability to exchange antibiotic resistance with other bacterial species (11). In addition, inappropriate use of antibiotics increases the risk of potentially fatal anaphylactic reactions and antibiotic side effects $(3,12,13,14)$ as well as patient demands and expectations for antibiotic therapy (3).

Due to the emergence of bacterial resistance, numerous studies have been conducted to date to evaluate the manner and cost/benefit effects of prescribing antibiotics in the therapy of oral and dental diseases (15-20).

The aim of this pilot study was to evaluate the type and the frequency of antibiotic prescribing by dental practitioners along with endodontic therapy in the Republic of Croatia. Besides, the aim was to assess whether Croatian doctors of dental medicine follow the guidelines on the use of antibiotic prophylaxis for the prevention of bacterial endocarditis and whether they accept endodontic treatment of patients at risk of developing bacterial endocarditis.

\section{Material and methods}

This study is a part of the dissertation: "Assessment of procedures in the performance of endodontic therapy in dental offices in the Republic of Croatia", which was approved by The Ethics Committee of the School of Dental Medicine of the University of Zagreb (05-PA.23.3/2018). For the purpose of this dissertation, a questionnaire containing about oko 1,8 milijuna doktora medicine (6) i oko 345.000 doktora dentalne medicine (7). Zbog toga se mora razmotriti doprinos pojedinih medicinskih struka pojavi bakterijske rezistencije na antibiotike $(3,5)$.

Osjetljivost bakterija u usnoj šupljini na antibiotike postupno se smanjuje, a raste broj rezistentnih vrsta, osobito Porphyromonas i Prevotella. (8). Također se navodi da se povećava otpornost alfa-hemolitičkih streptokoka (Streptococcus viridans) na djelovanje makrolida, penicilina i klindamicina $(9,10)$. Kad bakterija postane rezistentna na određeni antibiotik, ona može razmijeniti tu otpornost $s$ drugim bakterijama (11). Uz pojavu rezistencije, neracionalna uporaba antibiotika izlaže pacijente riziku od mogućih kobnih anafilaktičnih reakcija i drugih nuspojava $(3,12,13,14)$, a također povećava potražnju toga lijeka te očekivanja dobrobiti od antibiotske terapije (3).

Zbog pojave rezistentnosti bakterija do danas su provedene mnogobrojne studije u kojima se procjenjuju način, korisnost i šteta učinjena propisivanjem antibiotika u liječenju oralno-dentalnih bolesti $(15-20)$.

Svrha ove pilot-studije bila je procijeniti vrstu i učestalost primjene antibiotika kad je riječ o doktorima dentalne medicine koji pružaju endodontske usluge u kliničkoj praksi u Republici Hrvatskoj. Nadalje, željelo se procijeniti prate li hrvatski doktori dentalne medicine protokole za primjenu antibiotske profilakse u svrhu prevencije nastanka bakterijskog endokarditisa te prihvaćaju li endodontsko liječenje pacijenata s tim rizikom.

\section{Materijal i metode}

Ova pilot-studija dio je disertacije Procjena postupaka izvedbe endodontskih zahvata u ordinacijama dentalne medicine u Hrvatskoj. Ovo istraživanje odobrilo je Etičko povjerenstvo Stomatološkog fakulteta Sveučilišta u Zagrebu (05-PA.23.3/2018). Kako je bio potreban za disertaciju, oblikovan je anketni upitnik s oko 100 pitanja te su pitanja do-

Table 1 Questions about antibiotic administration

Tablica 1. Pitanja o uporabi antibiotika

Questions about antibiotic administration • Pitanja o uporabi antibiotika

1. Do you prescribe antibiotics with endodontic therapy? $\bullet$ Propisujete li antibiotike uz endodontski zahvat? never $\bullet$ nikad / very rarely $\bullet$ vrlo rijetko / rarely $\bullet$ rijetko / often $\bullet$ često / almost always $\bullet$ gotovo uvijek / always $\bullet$ uvijek

2. How often do you prescribe antibiotics for endodontic etiology problems? $\bullet$ Koliko često propisujete antibiotike za probleme endodontske etiologije? (once a day $\bullet 1$ puta/dan; two or more times a day $\bullet 2$ i više puta/dan; once or twice a week $\bullet 1-2$ puta/tjedan; more than twice a week $\bullet$ više od 2 puta/tjedan; once or twice a month $\bullet 1-2$ puta/mjesec; once or twice in several months $\bullet 1-2$ puta /više mjeseci)

3. What antibiotics are you most likely to prescribe to your patients for endodontic etiology problems? $\bullet$ Koje antibiotike najčešce propisujete svojim pacijentima za probleme endodontske etiologije?

4. For which diseases of the endodontic etiology do you most commonly prescribe antibiotics (you can tick more answers)? $\bullet$ Za koje bolesti endodontske etiologije najčešće propisujete antibiotike (možete zaokružiti više odgovora)? (answers offered • ponuđeni su odgovori)

5. How often do you prescribe an antibiotic without any local dental intervention on the cause of the endodontic problem? $\bullet$ Koliko često propisujete antibiotik, a da niste obavili nikakav tretman na zubu uzročniku endodontskog problema? never $\bullet$ nikad / very rarely $\bullet$ vrlo rijetko / rarely $\bullet$ rijetko / often $\bullet$ često / almost always $\bullet$ gotovo uvijek / always $\bullet$ uvijek

6. Do you accept to perform endodontic treatment in patients who need antibiotic prophylaxis to prevent infectious endocarditis? • Prihvaćate li endodontski liječiti zube pacijentima kojima je potrebna antibiotska profilaksa za prevenciju bakterijskog endokarditisa? never $\bullet$ nikad / very rarely $\bullet$ vrlo rijetko / rarely $\bullet$ rijetko / often $\bullet$ često / almost always $\bullet$ gotovo uvijek / always $\bullet$ uvijek

7. Are you familiar with the recent instructions (updates) on the use of antibiotic prophylaxis in bacterial endocarditis at-risk patients? $\bullet$ Pratite li recentne upute (promjene u uputama) za primjenu antibiotske profilakse u slučaju rizičnih pacijenata? yes/no $\bullet \mathrm{da} / \mathrm{ne}$ 
100 questions was designed and distributed to dental practitioners in the Republic of Croatia in printed and electronic forms. The electronic form is accessible at the following link: https://goo.gl/forms/DrT0AaM9Y2YeRUty2. Only the questions related to antibiotics were included in this study (Table 1).

Ninety (90) responses have been collected. Since seven questionnaires were answered by doctors who have not performed endodontic procedures in their clinical practice, their answers were not taken into account and a total of 83 questionnaires were processed (92\%).

\section{Results}

In this pilot study the results are evaluated as a percentage.

The distribution of the participating dental practitioners regarding educational groups is shown in Table 2.

The frequency of antibiotic prescriptions along with endodontic therapy is presented in Table 3. Table 4 presents the average number of antibiotics prescribed in predefined time intervals. Table 5 shows the most commonly prescribed antibiotics.

The percentage of practitioners who prescribe antibiotics for various endodontic diseases is presented in Table 6.

The description of antibiotic usage without any local dental treatment of the cause of the endodontic problem is presented in Table 7. The data regarding the answers about performing endodontic treatment for patients requiring antibiotic prophylaxis are shown in Table 8. Almost all surveyed dental practitioners $(96.7 \%)$ stated that they were familiar with the recent instructions (updates) on the use of antibiotic prophylaxis in at-risk patients. stavljena u tiskanom i elektroničkom obliku doktorima dentalne medicine u Republici Hrvatskoj. Elektronički oblik ankete dostupan je na stranici: https://goo.gl/forms/DrT0AaM9Y2YeRUty2. U ovoj studiji korišteni su samo podatci o propisivanju antibiotika (tablica 1.).

$\mathrm{Na}$ anketna pitanja odgovorilo je devedeset (90) liječnika. Budući da su sedam upitnika ispunili doktori koji ne obavljaju endodontske zahvate, njihovi odgovori nisu uzeti u obzir pa su ukupno obrađene 83 ankete (92\%).

\section{Rezultati}

U ovoj pilot-studiji rezultati su obrađeni kao postotci.

Raspodjela ispitanih doktora dentalne medicine prema skupinama (s obzirom na specijalizaciju) prikazana je u tablici 2 .

Učestalost propisivanja antibiotika u ordinacijama dentalne medicine tijekom endodontske terapije prikazana je u tablici 3. U tablici 4. je prosječan broj propisanih antibiotika u određenim vremenskim intervalima. $U$ tablici 5. su najčešće propisivani antibiotici.

Podatci o učestalosti propisivanja antibiotika za različite bolesti endodontske etiologije nalaze se u tablici 6 .

Podatci o učestalosti propisivanja antibiotika, a bez zahvata na zubu uzročniku, nalaze se u tablici 7. Odgovori na pitanje o liječenju pacijenata kojima je potrebna antibiotska profilaksa predstavljeni su u tablici 8 . Gotovo svi ispitanici $(96,7 \%)$ odgovorili su da prate recentne upute o primjeni antibiotske profilakse.

Table 2 Distribution of the participating dental practitioners regarding educational groups (\%)

Tablica 2. Prikaz raspodjele ispitanih doktora dentalne medicine prema skupinama

Group • Skupina

Dental practitioners $(\%)$ •

Doktori dentalne medicine $(\%)$ $(\mathrm{N}=90)$

General practitioners $\bullet$ doktori dentalne medicine bez specijalizacije $75.8 \%$

\begin{tabular}{l|l}
\hline Specialists and residents in endodontics and pedodontics $\bullet$ specijalisti i specijalizanti endodoncije i & $10.0 \%$
\end{tabular} pedodoncije

Specialists and residents in periodontology, oral surgery, oral medicine, prosthodontics and orthodontics $\bullet$ specijalisti i specijalizanti parodontologije, oralne kirurgije, oralnih bolesti, protetike, ortodoncije
$14.2 \%$

Table 3 Frequency of antibiotic prescriptions along with endodontic therapy (\%)

Tablica 3. Učestalost propisivanja antibiotika uz endodontski zahvat izražena kao postotak (\%)

Frequency of antibiotic prescription along with endodontic therapy • Učestalost propisivanja antibiotika uz endodontski zahvat

Dental practitioners (\%) •

Doktori dentalne medicine $(\%)$ ( $\mathrm{N}=83)$

\begin{tabular}{l|c} 
Never $\bullet$ Nikad & 9.6 \\
\hline Very rarely $\bullet$ Vrlo rijetko & 38.6 \\
\hline Rarely $\bullet$ Rijetko & 43.4 \\
\hline Often $\bullet$ Često & 8.4 \\
\hline Almost always $\bullet$ Gotovo uvijek & 0.0 \\
\hline Always $\bullet$ Uvijek & 0.0 \\
\hline
\end{tabular}


Table 4 Antibiotic administration along with endodontic therapy on a daily/weekly/monthly basis (\%)

Tablica 4. Prikaz primjene antibiotika uz endodontski zahvat na dnevnoj/tjednoj/mjesečnoj osnovi

Average of antibiotic administration along with endodontic therapy • Prosjek propisivanja antibiotka uz endodontski zahvat

Dental practitioners $(\%)$

Doktori dentalne medicine (\%) $(\mathrm{N}=83)$

Once a day $\bullet$ Jednom pacijentu / dan

Two or more times a day $\bullet$ Dvojici i više pacijenata / dan

Once or twice a week $\bullet$ Jednom do dva pacijenta / tjedan

More than twice a week $\bullet$ Više od dva pacijenta / tjedan

Once or twice a month $\bullet$ Jednom do dva pacijenta / mjesec

Once or twice in several months $\bullet$ Jednom do dva pacijenta / više mjeseci
2.4

1.2

20.5

2.4

41.0

32.5

Table 5 Presentation of the most commonly prescribed antibiotics for treatment of patients with endodontic etiology of dental disease (multiple-choice)

Tablica 5. Prikaz najčešće prepisivanih antibiotika za terapiju pacijentima s endodontskom etiologijom bolesti zuba (s mogućnošću upisivanja više odgovora)

Type of antibiotic $\bullet$ Vrsta antibiotika

Number of dental practitioners who marked that they use the type of antibiotic $\bullet$ Broj doktora dentalne medicine koji su zaokružili da se koriste navedenim antibiotikom

$(\mathrm{N}=83)$

penicillin (generally) • penicilin (općenito)

penicillin (Amoxicilin) • penicilin (Amoxicilin)

penicillin in combination with clavulanic acid (Klavocin, Augmentin) •

penicilin s klavulanskom kiselinom (Klavocin, Augmentin)

5

13

13

50

clindamycin (Klindamicin, Klimicin, Dalacin) • klindamicin (Klindamicin,

Klimicin, Dalacin)

metronidazole $($ Medazol) $\bullet$ metronidazol (Medazol)

Table 6 Frequency of antibiotic prescribing for various diseases of endodontic etiology (\%)

Tablica 6. Učestalost propisivanja antibiotika za različite bolesti endodontske etiologije (\%)

\section{Endodontic diseases $\bullet$ Bolesti endodontske etiologije}

Direct pulp capping $\bullet$ Direktno prekrivanje pulpe

Irreversible pulpitis $\bullet$ Ireverzibilni pulpitis

Pulp necrosis $\bullet$ Nekroza pulpe

Gangrene pulp $\bullet$ Gangrena pulpe

Localized acute apical periodontitis without swelling $\bullet$ Lokalizirani akutni apikalni parodontitis bez otekline

Diffuse spread of inflammation (cellulitis) • Difuzno širenje upale (celulitis)

Fever, enlarged lymph nodes $\bullet$ Povišena tjelesna temperatura, povećani limfni čvorovi

Tooth with fistula $\bullet$ Zub $s$ fistulom

Prophylaxis of infectious endocarditis $\bullet$ Profilaksa infektivnog endokarditisa

Along with one visit endodontic treatment $\bullet \mathrm{Uz}$ jednoposjetnu endodonciju
Dental practitioners who prescribe antibiotic (\%) • $\%$ doktora dentalne medicine koji propisuju antibiotike $(\mathrm{N}=83)$

0.0

6.0

1.2

26.2

51.2

85.0

75.0

16.9

94.1

15.5

Table 7 Frequency of antibiotic prescribing without any local dental treatment of the cause of the endodontic problem (\%)

Tablica 7. Učestalost propisivanja antibiotika bez zahvata na zubu uzročniku (\%)

Frequency of antibiotic prescribing without any local dental treatment • Učestalost propisivanja antibiotika bez zahvata na zubu uzročniku
Dental practitioners $(\%) \bullet$

Doktori dentalne medicine (\%) $(\mathrm{N}=83)$

Never $\bullet$ Nikad

Very rarely $\bullet$ Vrlo rijetko

Rarely $\bullet$ Rijetko

Often $\bullet$ Često

Almost always $\bullet$ Gotovo uvijek

Always • Uvijek
54.4

36.9

8.7

0.0

0.0

0.0 
Table 8 Number (\%) of dental practitioners who accept to perform endodontic therapy in patients at risk of developing infectious endocarditis

Tablica 8. Prikaz broja (\%) doktora dentalne medicine koji prihvaćaju endodontski liječiti zube pacijentima kojima je potrebna antibiotska profilaksa

Acceptance of endodontic dental treatment in patients at risk of infectious endocarditis • Prihvaćanje endodontskog liječenja zuba pacijentima s rizikom od pojave bakterijskog endokarditisa

Never • Nikad

Very rarely $\bullet$ Vrlo rijetko

Rarely $\bullet$ Rijetko

Often $\bullet$ Često

Almost always $\bullet$ Gotovo uvijek

Always $\bullet$ Uvijek
Dental practitioners (\%) •

Doktori dentalne medicine (\%) $(\mathrm{N}=83)$

5.5

9.8

8.7

19.6

16.3

40.1

\section{Discussion}

Nowadays, we are evaluating the appropriateness of antibiotic use in all fields of dental medicine (21-24). Since 1970, cross-sectional studies have been conducted on the use of antibiotics in dentistry, especially in endodontic clinical practice (21). Questionnaire surveys have been proven useful in such studies. The questions used in such surveys are usually about the types of antibiotic used, prescribing habits of dentists as determined by their age, gender, experience, expertise, educational degree and country area and frequency of antibiotic prescribing due to endodontic etiology (18-20). In these survey studies $(25,26)$ the overall response rate ranged between 30\% and 45\%. In our pilot study, we analyzed the first 90 survey questionnaires, which is what we have collected so far. It is too early to evaluate the response rate which is to be estimated at the end of the entire study.

In our study on the frequency of antibiotic prescribing, it can be concluded that 83 surveyed dental practitioners who perform endodontics in their clinical practice do not prescribe antibiotics frequently along with endodontic procedures (Table 3).

Regarding the question of antibiotic prescribing along with endodontic therapy on daily/weekly/monthly basis, $20.5 \%$ of dental practitioners in this survey prescribed antibiotics 1or 2 times a week and $41 \%$ of them prescribed antibiotics 1or 2 times a month (Table 4). Assuming that 17 dental practitioners prescribe antibiotics at least once a week (68 prescribed antibiotics a month), and 34 practitioners prescribe them once a month, we come to a total of 102 prescribed antibiotics a month just in the clinical practice of our first 83 surveyed dental practitioners who perform endodontic procedures in their clinical practice. We must also add $2.4 \%$ of dental practitioners who prescribe antibiotics once a day, $1.2 \%$ of them who prescribe antibiotics two or more times a day, and $2.4 \%$ of them who prescribe antibiotics more than two times a week, which is significantly increasing the number of prescribed antibiotics per month in the surveyed group of dental practitioners (ideally about 100 more antibiotics prescribed). If we compare the situation in Croatia with that in the UK, we can observe that $40 \%$ of dentists in the UK prescribed antibiotics at least three times each week, and 15\% prescribed antibiotics on a daily basis (4), which is evidently a much bigger consumption of antibiotics than in Croatia according to the results of our study.

\section{Rasprava}

U današnjoj stomatološkoj praksi, u svim područjima struke, preispitujemo racionalnost primjene antibiotika (21 -24). Od 1970. godine provode se presječna istraživanja o primjeni antibiotika u stomatologiji, posebno u endodontskoj kliničkoj praksi (21). Ankete su se pokazale uspješnima u takvim studijama, a pitanja u anketama su o vrsti propisanih antibiotika te rutini doktora dentalne medicine u propisivanju antibiotika s obzirom na dob, spol, iskustvo i stručnost te stupanj izobrazbe doktora, regiju u kojoj rade te frekvenciju ordiniranja antibiotika u svrhu endodontskog liječenja (18 20). U tim studijama $(25,26)$ ukupna stopa odgovora kretala se između 30 i $45 \%$. U ovoj pilot-studiji analizirali smo prvih 90 odgovorenih anketnih upitnika, a na kraju cijele studije bit će procijenjen postotak odgovorenih anketa.

U našoj studiji o učestalosti propisivanja antibiotika zaključuje se da 83 doktora sudionika ankete koji rade endodontske zahvate u sklopu svoje kliničke prakse ne propisuju često antibiotike uz endodontske zahvate (tablica 3.).

Na pitanje o propisivanju antibiotika uz endodontske zahvate na dnevnoj, tjednoj ili mjesečnoj osnovi, njih 20,5\% je odgovorilo da ih ordinira od 1 do 2 puta na tjedan, $41 \%$ od 1 do 2 puta na mjesec (tablica 4.). Pod pretpostavkom da 17 doktora dentalne medicine propiše antibiotik najmanje jedanput na tjedan (68 propisanih antibiotika mjesečno), a 34 doktora jedanput na mjesec, to ukupno iznosi 102 propisana antibiotika u mjesec dana u praksi samo tih 83 doktora. Tom broju moramo dodati i 2,4\% doktora dentalne medicine koji propišu antibiotik jednom pacijentu na dan, 1,2 \% koji to učine za dvoje i više pacijenata na dan te $2,4 \%$ onih koji propišu antibiotik za više od dvoje pacijenata na tjedan, što znatno povisuje broj ordiniranih antibiotika na mjesec u skupini tih 83 doktora (u najboljem slučaju oko 100 propisanih antibiotika više). Za usporedbu, u Ujedinjenom Kraljevstvu $40 \%$ doktora dentalne medicine propisuje antibiotike tri puta na tjedan, a $15 \%$ na dnevnoj bazi (4), što je očito mnogo veća konzumacija antibiotika od one koju je pokazao naš uzorak u Hrvatskoj.

Jasno istaknut problem, vidljiv iz odgovora u tablici 6., jest da velik broj ispitanih praktičara tretira antibioticima $\mathrm{i}$ endodontska stanja koja ne zahtijevaju takvo liječenje. Očito se ne uzima u obzir činjenica da antibiotici ne smanjuju bol, ni otekline na tkivu koje uzrokuje zub sa simptomatskom apikalnom patozom, a bez evidentnog sistemskog odgovo- 
From the answers in Table 6, it is clearly evident that a large number of surveyed dental practitioners prescribed antibiotics in cases of endodontic problems that did not require antibiotic support. Probably, practitioners do not take into account that antibiotics do not reduce the pain or swelling of the tissue resulting from symptomatic apical pathosis with no evident systemic response nor the pain resulting from irreversible pulpitis $(23,27,28)$. From the abovementioned, the obtained results justify the processing of this study among dental practitioners in the Republic of Croatia.

The situation is not significantly different in other European countries. Mainjot et al. (29) analyzed the antibiotic prescribing in dental practice within Belgium, concluding that antibiotics were prescribed to $63.3 \%$ of patients with periapical abscess and to $4.3 \%$ of patients with pulpitis. RodriguezNúnez et al. (25) reported that $40 \%$ of active members of the Spanish Endodontic Society prescribed antibiotics for cases of irreversible pulpitis, while $53 \%$ of them prescribed antibiotics in cases of a necrotic pulp, acute apical periodontitis and no swelling. The majority (84\%) of dental practitioners surveyed in Lithuanian study (30) reported antibiotic administration in cases of symptomatic apical periodontitis with periostitis and $2 \%$ of them in cases of symptomatic pulpitis. Among the members of the Spanish Oral Surgery Society (26), 86\% of respondents prescribed antibiotics for cases of irreversible pulpitis, and $71 \%$ of them administrated antibiotics in cases of necrotic pulp, acute apical periodontitis and no swelling. It is obvious that European dental practitioners, including the Croatian dental practitioners, prescribe antibiotics inappropriately and excessively when treating endodontic diseases.

According to the results of this study, $54.4 \%$ of dental practitioners did not prescribe antibiotics without intervention on susceptible tooth. On the other hand, $36.9 \%$ of dental practitioners rarely prescribed antibiotics without local dental treatment, while $8.7 \%$ of them rarely administrated antibiotics without any local interventions (Table 7). Mainjot et al. (29) reported that $54.2 \%$ of dental practitioners in Belgium administrated antibiotics with no local treatment.

According to data on commonly used antibiotics in endodontic therapy, penicillin antibiotics in combination with clavulanic acid and clindamycin were the most prevalent in this pilot study, while penicillins themselves were much less represented (Table 5). Metronidazole has most probably been used as an adjunct antibiotic in addition to penicillins in the treatment of more complex cases. According to Macan's (31) study, amoxicillin with clavulanic acid was the most effective antibiotic in the treatment of dental infections if the local dental intervention on the causative teeth was performed. If there had not been any improvement in the following two days, additional metronidazole would have been administered. Our results are comparable to those of Perić et al. (19) on the use of antibiotics in Zagreb in 2015, according to which the use of penicillin antibiotics was observed in the treatment of dental diseases in $72.5 \%$ of cases, in $57.6 \%$ of which penicillins were combined with clavulanic acid.

In other studies $(25,26,29,30,32)$ amoxicillin was the first antibiotic of choice in the treatment of endodontic infections, while clindamycin was the first drug of choice for ra, kao ni bol uzrokovanu ireverzibilnim pulpitisom (23, 27, 28). Zbog navedenoga dobiveni rezultati opravdavaju provođenje ove studije među doktorima dentalne medicine u Republici Hrvatskoj.

Stanje nije bitno drukčije ni u drugim europskim zemljama. Mainjot i suradnici (29), analizirajući belgijsku praksu u propisivanju antibiotika, zaključili su da se antibiotici propisuju za $63,3 \%$ pacijenata s periapikalnim apscesom i 4,3 $\%$ pacijenata s pulpitisom. Rodriguez-Núńez i suradnici (25) istaknuli su da 40 \% aktivnih članova Španjolskoga endodontskog društva daje antibiotik u slučaju ireverzibilnog pulpitisa, a $53 \%$ za nekrozu pulpe i akutni apikalni parodontitis bez otekline. U Litvi (30) $84 \%$ ispitanih doktora dentalne medicine propisuje antibiotike za simptomatski apikalni parodontitis s periostitisom, a njih $2 \%$ za simptomatski pulpitis. U slučaju članova Španjolskoga kirurškog društva (26), $86 \%$ anketiranih članova daje antibiotik tijekom terapije ireverzibilnog pulpitisa, a njih $71 \%$ za nekrozu pulpe te akutni apikalni parodontitis bez otekline. Iz navedenoga očito je da, osim za bolesti endodontske etiologije, europski doktori dentalne medicine, uključujući i hrvatske, antibiotike propisuju neprimjereno i prekomjerno.

Prema rezultatima iz ove studije, 54,4\% doktora dentalne medicine ne propisuje antibiotike bez provedenoga lokalnog stomatološkog tretmana. No njih 36,9 \% vrlo rijetko ih ordinira bez stomatološkog tretmana, a $8,7 \%$ rijetko daje antibiotik bez zahvata na zubu. Mainjot i suradnici (29) istaknuli su da u Belgiji doktori dentalne medicine propisuju antibiotike bez dentalnoga zahvata u 54,2 \% slučajeva.

Prema podatcima o najčešće rabljenim antibioticima u endodontskoj terapiji, u ovoj pilot-studiji najzastupljeniji su bili penicilinski antibiotici s dodatkom klavulanske kiseline te klindamicin, a sami penicilini bili su znatno manje zastupljeni (tablica 5.). Metronidazol je primjenjivan kao pomoćni antibiotik uz peniciline u terapiji zahtjevnijih slučajeva. Prema Macanovu (31) istraživanju, u terapiji upala dentalnog podrijetla, najdjelotvorniji je bio amoksicilin $s$ klavulanskom kiselinom ako je proveden i stomatološki tretman zuba uzročnika, a ako nije bilo poboljšanja tijekom iduća dva dana, ordiniran je metronidazol. Naši rezultati u skladu su s rezultatima studije Perića i suradnika (19) o uporabi antibiotika u Zagrebu iz 2015. godine prema kojoj je u terapiji bolesti zubnog podrijetla u $72,5 \%$ slučajeva zabilježena primjena penicilinskih antibiotika, a od toga su u 57,6 \% bili kombinirani penicilini s klavulanskom kiselinom.

U drugim studijama $(25,26,29,30,32)$ je amoksicilin antibiotik prvog izbora u liječenju endodontskih infekcija, a u slučaju alergije koriste se klindamicin $(19,25,26,32)$ te eritromicin (29). U turskoj studiji iz 2000. godine (33) antibiotik izbora bio je ampicilin, a u najnovijoj studiji provedenoj u toj zemlji 2019. godine, prvi izbor je amoksicilin s klavulanskom kiselinom (20).

Rezultati ove ankete pokazali su da je $76 \%$ ispitanika odgovorilo da često, gotovo uvijek i uvijek prihvaća endodontski liječiti zube pacijentima kojima je potrebna antibiotska profilaksa za prevenciju bakterijskog endokarditisa (tablica 8.), a $96,7 \%$ odgovorilo je da prati recentne upute za profilaksu rizičnih pacijenata. 
patients with allergy $(19,25,26,32)$. Besides, erythromycin was (29) used. According to one Turkish study, in 2000 (33) the antibiotic of choice was ampicillin, while a Turkish most recent study suggests that, in 2019, amoxicillin with clavulanic acid was the first antibiotic of choice (20).

The results of this study showed that $76 \%$ of participants often/almost always/ always accept endodontic treatment in patients requiring antibiotic prophylaxis to prevent infectious endocarditis (Table 8), and $96.7 \%$ of participants stated that they were familiar with recent instructions for antibiotic prophylaxis.

Considering that $75.8 \%$ of those surveyed in this study were general dental practitioners, $14.2 \%$ were specialists and residents in the field of dental medicine, who had not necessarily performed endodontic treatment, and only $10 \%$ were specialists and residents in endodontics and pedodontics (Table 2), the results have shown that a high percentage of nonspecialist practitioners perform endodontic procedures in bacterial endocarditis at-risk patients, even though endodontic procedures may be extremely demanding.

In this pilot study, the impacts of other variables such as age, gender, years of work, education, etc. were not evaluated due to a small number of responses received for this survey. These variables will be addressed at the end of the study.

\section{Conclusion}

The results of this pilot study show that there is inappropriate use of antibiotics in the practice of 83 dental practitioners questioned regarding frequency of administration and indications. The most commonly used antibiotic is penicillin with clavulanic acid. A high percentage of surveyed practitioners have stated that they are familiar with most recent instructions for antibiotic prophylaxis. In addition, they have stated that they perform endodontic procedures in bacterial endocarditis at-risk patients.

Although this is a pilot study with known limitations (a small number of respondents as well as small number of questions), there is a noticeable need for targeted continuing education of dental practitioners in the Republic of Croatia.

\section{Conflict of interest}

\section{None declared}

\section{Authors' contribution}

J.S. - is the first author; this pilot study is part of the research for her dissertation. She actively participated in all the activities of designing and writing this text; $\boldsymbol{S} . \check{S}_{\text {. }}$ - is a mentor of this dissertation, participated in the creation of research and all the activities related to text writing; I.T. - is a comentor on the dissertation, participated in the design and implementation of the survey, data processing and consultations with the doctoral student; B.Ž. - participated in the professional processing and interpretation of research results, and in consultations in writing the text; I.S. - participated in the expert interpretation of the results and consultations with the doctoral student; I.A. participated in the creation of the research and all the activities related to making and writing of this text.
S obzirom na to da su $75,8 \%$ ispitanih u ovoj studiji bili doktori dentalne medicine bez specijalizacije, a 14,2\% specijalisti i specijalizanti koji ne obavljaju nužno endodontska liječenja, te samo $10 \%$ specijalisti i specijalizanti endodoncije i pedodoncije (tablica 2), rezultati pokazuju da visok postotak doktora obavlja endodontska liječenja rizičnim pacijentima, s obzirom na to da su endodontski postupci uglavnom iznimno zahtjevni.

U ovoj pilot-studiji nisu evaluirani utjecaji ostalih ispitivanih varijabli poput dobi, spola, godina rada u struci, edukacije i slično zbog malog broja obrađenih odgovorenih upitnika, pa će navedeno biti obrađeno na kraju studije.

\section{Zaključak}

Rezultati pilot-studije upozoravaju na neprimjerenu uporabu antibiotika u praksi na temelju odgovora 83 doktora dentalne medicine, $s$ obzirom na učestalost primjene i indikacije. Najčešće primjenjivani antibiotik je penicilin s klavulanskom kiselinom. Doktori dentalne medicine koji su odgovorili na anketna pitanja u velikom postotku su istaknuli da prate recentne upute o profilaksi bakterijskog endokarditisa te da prihvaćaju endodontski liječiti zube rizičnim pacijentima kojima je potrebna antibiotska profilaksa za prevenciju bakterijskog endokarditisa. Iako je ovo pilot-studija s poznatim ograničenjima (mali broj ispitanika i mali broj postavljenih pitanja), jasno upozorava da je potrebna ciljana i trajna edukacija doktora dentalne medicine u Republici Hrvatskoj.

\section{Sukob interesa}

Autori nisu bili u sukobu interesa.

\section{Doprinos autora}

J. S. - prvi je autor, ova pilot-studija u sklopu je istraživanja za njezinu disertaciju; aktivno je sudjelovala u svim fazama izrade i pisanja ovog teksta; S. Š. - mentorica je autorice i sudjelovala je u kreiranju istraživanja te u svim fazama izrade i pisanja ovog teksta; I. T. - sumentor je i sudjelovao je u osmišljavanju i izvedbi ankete, obradi podataka te konzultacijama s doktorandicom; B. Ž. - sudjelovao je u stručnoj obradi i interpretaciji rezultata istraživanja te u konzultacijama pri pisanju teksta; I. $\check{S}_{\text {. }}$ - sudjelovala je u stručnoj interpretaciji rezultata i konzultacijama s doktorandicom; I. A. sudjelovao je u kreiranju istraživanja te u svim fazama izrade i pisanja ovog teksta 


\section{Sažetak}

Cilj: Željelo se procijeniti vrstu i učestalost primjene antibiotika tijekom endodontskih zahvata u Republici Hrvatskoj te procijeniti stajalište liječnika dentalne medicine o endodontskom liječenju pacijenata rizičnih za nastanak bakterijskog endokarditisa. Materijal i metode: Podatci su skupljeni ispunjavanjem anketnih upitnika. Rezultati: Među liječnicima koji su odgovorili na anketna pitanja njih 8,4 \% istaknulo je da propisuje antibiotike često, a 91,6 \% nikada, vrlo rijetko ili rijetko. Većina njih (41\%) ordinirala je antibiotike jedanput ili dva puta na mjesec, 32,5 \% jedanput ili dva puta u nekoliko mjeseci, a 20,5\% jedanput ili dva puta na tjedan. Najčešće korišteni antibiotik bio je penicilin s klavulanskom kiselinom. Zatim, 26,2 \% liječnika propisivalo je antibiotike za gangrenu pulpe, 51,2 \% za lokalizirani akutni apikalni parodontitis bez otekline, $85 \%$ za celulitis, $75 \%$ za povišenu tjelesnu temperaturu i povećane limfne čvorove, $16,9 \%$ za zub s fistulom i 94,1 \% za profilaksu bakterijskog endokarditisa. Prema rezultatima studije 54,4\% stomatologa nije propisivalo antibiotike bez intervencije na osjetljivom zubu, 76 \% često je, gotovo uvijek, ili uvijek prihvatilo endodontsko liječenje bolesnika kojima je bila potrebna antibiotska profilaksa zbog sprječavanja infektivnog endokarditisa, a 96,7\% sudionika odgovorilo je da zna za nedavne upute o antibiotskoj profilaksi. Zaključak: Rezultati upozoravaju na neprimjerenu uporabu antibiotika u praksi na temelju odgovora 83 doktora dentalne medicine, s obzirom na učestalost primjene i indikacije. Najčešće korišteni antibiotik bio je penicilin s klavulanskom kiselinom. Visok postotak anketiranih odgovorio je da su im poznate recentne upute o antibiotskoj profilaksi te da obavljaju endodontske zahvate i pacijentima rizičnima za razvoj bakterijskog endokarditisa. Potrebna je ciljana trajna edukacija doktora dentalne medicine u Republici Hrvatskoj.
Zaprimljen: 11. lipnja 2020.

Prihvaćen: 24. kolovoza 2020.

Adresa za dopisivanje

Sanja Šegović

Sveučilište u Zagrebu, Stomatološki fakultet

Zavod za endodonciju i restaurativnu stomatologiju

Gundulićeva 5

10000 Zagreb

tel: 4802111

segovic@sfzg.hr

Ključne riječi

endodontski tretman; propisivanje lijekova; antibiotska profilaksa; bakterijski endokarditis

\section{References}

1. Siqueira JF, Roças I. Present status and future directions in endodontic microbiology. EndodTopics. 2014; 30: 3-22.

2. Grgurević J, Ivanišević Malčić A, Tambić Andrašević A, Prpić Mehičić G, Kuzmac S, Jukić S. Učestalost nalaza bakterijskog sadržaja u perzistentnim periapikalnim lezijama. Acta Stomatol Croat. 2017 Sep;51(3):217-226

3. Lewis MAO. Why we must reduce dental prescription of antibiotics: European Union Antibiotic Awareness Day. Br Dent J. 2008 Nov 22;205(10):537-8.

4. Segura-Egea JJ, Gould K, Hakan Şen B, Jonasson P, Cotti E, Mazzoni A,Sunay H,Tjäderhane L, Dummer PMH. European Society of Endodontology position statement: the use of antibiotics in end odontics. Int Endod J. 2018; 51 : 20-5.

5. Cope AL, Chestnutt IG. Inappropriate prescribing of antibiotics in primary dental care: reasons and resolutions. Prim Dent J. 2014 Nov;3(4):33-7.

6. MeSH Browser [database on the Internet]. Eurostat: physician statistic explained-european comission; Nov 29, 2019 [cited 2020 Apr 07]. Available from: https://ec.europa.eu/eurostat/statistics-explained/pdfscache/37382.pdf

7. MeSH Browser [database on the Internet]. 345.000 dentist prac tise i European Union. March 1, 2017 [cited 2020 Apr 07]. Available from: https://eu.dental-tribune.com/news/345000-dentists-practise-in-the-european-union/

8. Bresco-Salinas M, Costa-Riu N, Berini-Aytes L, Gay-Escoda C. Susceptibilidad antibiotica de las bacterias causantes de infecciones odontog enicas. Med Oral Patol Oral Cir Bucal. 2006 Jan 1;11(1):E47-51.

9. Aracil B, Minambres M, Oteo J, Torres C, Gomez-Garces JL, Alos JI. High prevalence of erythromycin-resistant and clindamycin-susceptible ( $M$ phenotype) viridans group streptococci from pharyngeal samples: a reservoir of mef genes in commensal bacteria. Antimicrob Chemoth. 2001; 48: 592-4.

10. Groppo FC, Simoes RP, Ramacciato JC, Rehder V, de Andrade ED, Mattos-Filho TR. Effect of sodium diclofenac on serum and tissue concentration of amoxicillin and on staphylococcal infection. Biol Pharm Bull. 2004 Jan;27(1):52-5.

11. Jungermann GB, Burns K, Nandakumar R, Tolba M, Venezia RA Fouad AF. Antibiotic resistance in primary and persistent endodontic infections. I Endod. 2011 Oct;37(10):1337-44.

12. Negovetić Vranić D, Jurković J, Jeličić J, Balenović A, Stipančić G, Čuković-Bagić I. Hitna stanja u dječjoj stomatologiji. Acta stomatol Croat. 2016;50(1):72-80.

13. Gonzales R, Malone DC, Maselli JH, Sande MA. Excessive antibiotic use for acute respiratory infections in the United States. Clin Infect Dis. 2001 Sep 15;33(6):757-62.

14. Costelloe C, Metcalfe C, Lovering A, Mant D, Hay A. Effect of an tibiotic prescribing in primary care on antimicrobial resistance in individual patients: systematic review and meta-analysis. BMJ. 2010 May 18;340:c2096.

15. Al-Haroni M, Skaug N. Knowledge of prescribing antimicrobials among Yemeni general dentists. Acta Odontol Scand. 2006;64(5):274-80.

16. Dar-Odeh NS, Abu-Hammad OA, Khraisat AS, El Maaytah MA, Shehabi A. An analysis of therapeutic, adult antibiotic prescriptions issued by dental practitioners in Jordan. Chemotherapy. 2008;54(1):17-22.
17. Öcek Z, Sahin H, Baksi G, Apaydin S. Development of a ratio nal antibiotic usage course for dentists. Eur J Dent Educ. 2008 Feb;12(1):41-7.

18. Murti A, Morse Z. Dental antibiotic prescription in Fijian adults. Int Dent J. 2007 Apr;57(2):65-70.

19. Peric M, Perkovic I, Romic M, Simeon P, Matijević J, Prpić Mehičić $G$, et al. The pattern of antibiotic prescribing by dental practitioners in Zagreb, CroatiaCent Eur J Public Health. 2015 Jun;23(2):107-13.

20. Aydın M, Koyuncuoğlu CZ, Kırmızı İ, İşli F, Aksoy M, Alkan A, et al. Pattern of Antibiotic Prescriptions in Dentistry in Turkey: Population Based Data from the Prescription Information System. Infect Dis Clin Microbiol. 2019; 1 (2): 62-9.

21. Segura-Egea JJ, Gould K, Hakan Şen B, Jonasson P, Cotti E, Mazzoni A,Sunay H,Tiäderhane L, Dummer PMH. Antibiotics in Endodontics: a review. Int Endod J. 2017; 50(12):1169-84.

22. Dar-Odeh NS, Abu-Hammad OA, Al-Omiri MK, Khraisat AS, Shehabi AA. Antibiotic prescribing practices by dentists: a review. Ther Clin Risk Manag. 2010 Jul 21;6:301-6.

23. Aminoshariae A, Kulild JC. Evidence-based recommendations for antibiotic usage to treat endodontic infections and pain: A systematic review of randomized controlled trials. J Am Dent Assoc. 2016 Mar;147(3):186-91.

24. Palmer NOA. Antimicrobial Resistance and Antibiotic Prescribing in Dental Practice. Dent Update. 2016 Dec;43(10):954-58, 960.

25. Rodriguez-Nunez A, Cisneros-Cabello R, Velasco-Ortega E, Lla mas-Carreras JM, Torres-Lagares D, Segura-Egea JJ. Antibiotic use by members of the Spanish Endodontic Society. J Endodont. 2009; 35:1198-203.

26. Segura-Egea JJ, Velasco-Ortega E, Torres-Lagares D, Velasco-Ponferrada MC, Monsalve-Guil L, LLamas-Carreras IM. Pattern of antibiotic prescription in the management of endodontic infections among Spanish oral surgeons. Int Endod J. 2010 Apr;43(4):342 50 .

27. Keenan JV, Farman AG, Fedorowicz Z, Newton JT. A Cochrane sys tematic review finds no evidence to support the use of antibiotics for pain relief in irreversible pulpitis. J Endod. 2006 Feb;32(2):87 92.

28. Cope A, Francis N, Wood F, Mann MK, Chestnutt IG. Systemic antibiotics for symptomatic apical periodontitis and acute apical abscess in adults. Cochrane Database Syst Rev. 2014 Jun 26;(6):CD010136.

29. Mainjot A, D'Hoore W, Vanheusden A, Van Nieuwenhuysen IP. Antibiotic prescribing in dental practice in Belgium. Int Endod J. 2009 Dec;42(12):1112-7.

30. Skucaite N, Peciuliene V, Maneliene R, Maciulskiene V. Antibiotic prescription for the treatment of endodontic pathology: a survey among Lithuanian dentists. Medicina (Kaunas). 2010;46(12):80613.

31. Macan K. Primjena antimikrobnih lijekova u stomatologiji. Sonda. 2003;5:8-9.

32. Kaptan RF, Haznedaroglu F, Basturk FB, Kayahan MB. Treatment approaches and antibiotic use for emergency dental treatment in Turkey. Ther Clin Risk Manag. 2013;9:443-9.

33. Kandemir S, Ergul N. Grievances in cases using antibiotics due to orodental problems and assessment of the need for antibiotics. Int Dent J. 2000 Apr;50(2):73-7. 